\title{
Variability in establishing white clover in pastures on farms
}

\author{
J.L. BROCK ${ }^{1}$ and G.J. KANE ${ }^{2}$ \\ ${ }^{1}$ AgResearch, Grasslands Research Centre, PB 11008, Palmerston North \\ ${ }^{2}$ Dairy farmer R.D. 4, Palmerston North \\ john.brock@agresearch.co.nz
}

\begin{abstract}
Reported problems with inconsistent white clover establishment in pastures prompted a MAF SFF project to investigate the causes. The establishment of white clover in 32 new and renovated paddocks on 16 farms in the Wanganui-Manawatu-Southern Hawke's Bay region was monitored and the inconsistency confirmed in the first year. Seedling emergence at $44 \%$ (range 22 to 84 ) for ryegrass and 35\% (range 9 to 73 ) for white clover was low (expected $70 \%+$ ) and inappropriate grazing management inhibited subsequent plant growth and sward performance to $20 \%$ of potential. There were a few good performances, but the 'grass to grass' technique was particularly hard on clover. These problems have arisen as a result of modern methods (e.g. direct drilling and fertiliser N) that are less 'clover friendly', and have moved away from the older proven techniques. Minimal seedbed preparation and method of sowing, combined with lack of knowledge of white clover growth strategies and management requirements are seen as the main causes. Change is inescapable and while modern farming techniques and expectations may have currently placed clover at a disadvantage, the challenge now is how to balance the requirements of the pasture species with the expectations of the farming production system in the future.
\end{abstract}

Keywords: emergence, establishment, farmer knowledge, grazing management, life cycle, sowing conditions, white clover.

\section{Introduction}

"We can't get enough white clover", a comment often heard from New Zealand farmers in recent years. For a country with a 70 year history of plant improvement and scientific study into the plant regarded as "the key to the international competitive advantage of New Zealand's pastoral industries, through its ability to fix nitrogen, and high nutritive value' (Caradus et al. 1996), it has been widely assumed that we should know how to get the best out of white clover. However, with increasing reports of farmers having problems with the initial establishment and persistence beyond 1-3 years of white clover (Fraser 2000), this is clearly not the case. Why?
To advance the issue, a MAF Sustainable Farming Fund grant was approved in 2001 to investigate the problem of white clover establishment under current farming practices. The paper is a report of the first year's findings.

\section{Methods}

'Normal' farm pasture establishment was monitored on 32 new paddocks on 16 farms in the WanganuiManawatu-Southern Hawke's Bay region, covering a range of enterprises (6 dairy and 10 sheep/beef of which 3 were intensive finishing and 7 breeding stock), environments and soils from summer dry coastal sand country to moist hill country. For each paddock, notes on paddock history, soil type and seedbed conditions, preparation, seed rate and sowing methods were taken, the soil sampled for chemical analysis (E-lab Ltd), soil moisture and soil compaction. In nearly all paddocks, resident vegetation was controlled by spraying with 'Roundup' at 1-4 litres/ha before drilling. Following sowing in autumn 2002, counts of seedling emergence were made 4-6 weeks later and plant growth data collected through to the following summer, along with information on grazing management practice and environmental conditions, in order to identify issues affecting establishing white clover seedlings. Wherever possible, results are compared with a 'research standard', in this case an autumn sown trial established in 1995 on a sandy loam soil in which pasture establishment procedures developed by the 1960 's were used i.e. soil $\mathrm{N}$ reduced by cropping, lower grass seeding rate, consolidated seed bed, broadcast by roller drill followed by light harrows and rolling, then grazed by sheep during establishment.

\section{Results}

The season

The 2002 season was probably more difficult for establishing new pastures compared to the 1995 'research standard' (Table 1). A dry mid-March effectively split the sowing dates into early and late groups, while the wet winter (June/July) made timing of the first grazings difficult and the dry, cool spring (daily maximum temperatures $3-4^{\circ} \mathrm{C}$ below average) 
Table 1 A comparison of monthly rainfall and maximum air temperatures at Palmerston North for 1995 ('research standard') and 2002.

\begin{tabular}{|c|c|c|c|c|}
\hline \multirow[t]{2}{*}{ Month } & \multicolumn{2}{|c|}{$\begin{array}{c}\text { Rainfall - } \\
(\mathrm{mm})\end{array}$} & \multicolumn{2}{|c|}{$\begin{array}{c}\text { Maximum } \\
\text { temperature }\left({ }^{\circ} \mathrm{C}\right)\end{array}$} \\
\hline & 1995 & 2002 & 1995 & 2002 \\
\hline March & 142 & 81 & 21.1 & 21.3 \\
\hline April & 104 & 56 & 19.7 & 17.4 \\
\hline May & 108 & 66 & 15.8 & 15.2 \\
\hline June & 94 & 134 & 12.9 & 14.2 \\
\hline July & 121 & 136 & 11.7 & 12.1 \\
\hline August & 73 & 86 & 12.5 & 12.8 \\
\hline September & 106 & 99 & 15.2 & 14.7 \\
\hline October & 140 & 68 & 16.7 & 14.4 \\
\hline November & 102 & 45 & 18.1 & 15.9 \\
\hline December & 101 & 85 & 21.9 & 19.5 \\
\hline
\end{tabular}

was not conducive to good plant growth and development. December showed a recovery to normal summer conditions, but was followed by a prolonged late summer/autumn drought.

Seedling emergence and growth in the first winter On average, the emergence rate of grass and clover was poor compared to the 'research standard' (Table $2)$. Ryegrass emergence rate was in the main unaffected, the exception being paddock history, where emergence rates were higher in direct drilled grass to grass situations.

For white clover, emergence rate and growth was poorer in clay soils where the soil was hard and glazed

Table 2 The effect of soil type and sowing procedures on seedling emergence and white clover plant growth during winter.

\begin{tabular}{lccc}
\hline $\begin{array}{l}\text { Soil/cultural } \\
\text { practice }\end{array}$ & $\begin{array}{c}\text { \% emergence } \\
\text { Clover } \pm \text { SEM }\end{array}$ & $\begin{array}{c}(4-6 \text { weeks }) \\
\text { Grass } \pm \text { SEM }\end{array}$ & $\begin{array}{c}\text { Stolon DW }(\mathrm{mg}) \\
\text { at 5-6 months }\end{array}$ \\
\hline $\begin{array}{l}\text { 'Research std' } \\
\text { Soil }\end{array}$ & $85 \pm 1.8$ & $77 \pm 1.4$ & \\
Clay & $28 \pm 7.1$ & $46 \pm 7.5$ & $16 \pm 2.0$ \\
Loam & $37 \pm 3.9$ & $42 \pm 2.9$ & $27 \pm 7.2$ \\
Sand & $40 \pm 6.4$ & $47 \pm 6.9$ & $22 \pm 3.8$ \\
Paddock history & & & \\
Crop & $40 \pm 7.6$ & $36 \pm 3.4$ & $36 \pm 16.4$ \\
Green feed & $38 \pm 4.1$ & $40 \pm 2.9$ & $26 \pm 5.4$ \\
Grass to grass & $29 \pm 4.6$ & $54 \pm 5.0$ & $15 \pm 2.5$ \\
Cultivation & & & \\
Yes & $44 \pm 4.2$ & $44 \pm 4.1$ & $22 \pm 4.7$ \\
No & $29 \pm 3.9$ & $44 \pm 3.3$ & $26 \pm 7.8$ \\
Seedbed & & & \\
Friable & $46 \pm 4.4$ & $42 \pm 3.8$ & $30 \pm 9.7$ \\
Loose, blocky & $31 \pm 3.4$ & $44 \pm 4.3$ & $26 \pm 4.2$ \\
Hard, glazed & $25 \pm 5.4$ & $46 \pm 5.7$ & $14 \pm 1.8$ \\
Sowing date & & & \\
Early & $39 \pm 7.3$ & $43 \pm 4.7$ & $43 \pm 13.1$ \\
Late & $34 \pm 3.2$ & $44 \pm 3.1$ & $17 \pm 1.7$ \\
Drill & & & \\
X slot & & & \\
Others & $30 \pm 3.6$ & $45 \pm 3.3$ & $26 \pm 6.5$ \\
Mean (\& range) & $35(9-73)$ & $44(22-84)$ & \\
\hline
\end{tabular}

44 - File identification only going from 'grass to grass'. Where sowing had been preceded by a crop (cereals, peas), growth tended to be better. Sowing date had no effect on emergence rate, but as could be expected, plants from early sowings had more than twice the weight (and spread with $40 \%$ more branches) of those sown later. Cultivation to form a fine, friable surface increased clover emergence. The X-slot drill was the most widely used $(62 \%)$ and on average gave lower clover and higher grass emergence rate compared to the other types of drills (e.g. Aitcheson triple disc).

\section{Clover performance during spring and summer}

With the poor emergence and the wet weather, white clover seedling numbers in winter were low but were $60 \%$ greater in 'new' (following a crop or green feed) than 'renovated' pastures ('grass to grass') and declined at a slower rate to have 6 times more plants by summer although surviving plants in both groups were of similar size (Table 3). On average, individual plants grew as well as the 'research standard' during

Table 3 A comparison of plant survival and size from winter to summer in new or renovated pastures.

\begin{tabular}{lccc}
\hline Pasture & - Winter - & & \multicolumn{2}{c}{ Summer } \\
\cline { 3 - 4 } & $\left(\right.$ seedlings $\left./ \mathrm{m}^{2}\right)$ & (plants $\left./ \mathrm{m}^{2}\right)$ & (stolon DW/plant) \\
\hline Renovation & $90 \pm 20$ & $14 \pm 4.0$ & $417 \pm 110$ \\
New & $146 \pm 16$ & $83 \pm 12$ & $406 \pm 64$ \\
\hline
\end{tabular}

winter (stolon number and DW, Table 4), but growth fell behind in the cooler spring. Three exceptions (not presented) occurred, where paddocks were sown early, out of crop, on freer draining soils with low grass competition (slower establishing tall fescue or low ryegrass emergence) and grazed predominantly by beef cattle. Spring grazing management had clear effects on plant growth (Table 4), when set stocking with sheep from early spring reduced plant development and growth which never fully recovered, whereas rotational grazing with cattle resulted in plants larger than the 'research standard'. Compared to the 'research standard', the overall performance of the group was poor (Table 5) with generally lower stolon density and plant numbers, partly due to the cool spring, off-set to some degree by larger plants in the better performing paddocks mentioned above (tall fescue under cattle grazing). The clover in the equivalent ryegrass based pastures produced reasonable plant 
Table 4 The development of white clover plants (stolon number and plant DW) from winter to summer comparing the best group results for sheep (set stocked spring) and cattle (rotationally grazed) with the group mean and a 'research standard' (rotationally grazed sheep) results.

\begin{tabular}{|c|c|c|c|c|}
\hline \multirow[b]{2}{*}{ Days from sowing } & \multicolumn{4}{|c|}{ Stolon number (and mg DW) per plant } \\
\hline & $\begin{array}{c}65 \\
\text { (early winter) }\end{array}$ & $\begin{array}{c}110 \\
\text { (mid winter) }\end{array}$ & $\begin{array}{c}185 \\
\text { (early spring) }\end{array}$ & $\begin{array}{c}335 \\
\text { (mid summer) }\end{array}$ \\
\hline 'Research standard' (19 April) & - & $2.3(8)$ & $7.4(90)$ & $18(460)$ \\
\hline Group mean & $1.5(1)$ & $2.5(11)$ & $3.1(24)$ & $12(345)$ \\
\hline Best set stocked sheep (28 March) & $1.6(2)$ & $2.9(53)$ & $7.2(36)$ & $9(300)$ \\
\hline Best rotationally grazed cattle (8 March) & $3.3(6)$ & $6.2(42)$ & $12(126)$ & $44(775)$ \\
\hline
\end{tabular}

Table 5 A comparison of the best group paddocks with the group mean and 'research standard' in summer, 10 months after sowing (performance = stolon density X plant DW as a percentage of the 'research standard' performance at 100).

\begin{tabular}{llcccc}
\hline Establishment method & \multicolumn{1}{c}{ History } & Stolon density & Plants/m² & Plant DW & Performance \\
\hline $\begin{array}{l}\text { 'Research standard' } \\
\text { ryegrass/sheep }\end{array}$ & $\begin{array}{l}\text { Tama ryegrass } \\
\text { cultivated, broadcast }\end{array}$ & 4950 & 270 & 460 & 100 \\
Group (new pastures) & - & 1150 & 83 & 405 & 20 \\
Tall fescue/cattle & Cereal, direct drilled & 1870 & $120^{*}$ & 1134 & 93 \\
Tall fescue/cattle & Peas, direct drilled & 1855 & 42 & 775 & 63 \\
Ryegrass/sheep & Cereal, cultivated, direct drilled & 2860 & 147 & 442 & 56 \\
Ryegrass/sheep & Turnips, direct drilled & 2645 & 150 & 288 & 33 \\
\hline * estimated, soil too stony to sample. & & & &
\end{tabular}

* estimated, soil too stony to sample.

numbers but at a lower DW and performed at half the level. On average, only 25\% (range 5-50) of plants in renovated pastures ('grass to grass') came from sown seed, but combined with the clonal plants making up the remainder of the population, their performance was slightly better than that of the new pastures.

\section{Discussion}

Plant establishment is a combination of seedling emergence and survival. The results of the first year of the project confirmed the general inconsistency of white clover establishment in pastures (Table 2). Not a great year weather-wise for establishing new pastures (Table 1), the range of results indicates that the use of 'inappropriate' sowing techniques (lack of seedbed preparation and control of sowing depth) and establishment management practices (too short, set stocking in spring), combined in the main, to create an environment that is no longer 'clover friendly'. Nevertheless, there were some instances of good results being obtained.

How has this poor establishment of white clover in pastures come about? Recent evolution of farming systems to maintain cost effectiveness has seen the rapid development of a new generation of techniques (e. g. grass to grass direct drilling and minimum tillage, high fertility soils and $\mathrm{N}$ fertiliser, a wide range of new rapidly establishing grass cultivars, particularly the hybrid or short-rotation ryegrasses) to the apparent disadvantage of white clover. The emphasis has changed to maximising production with minimal down time, really achievable only through the grass component now that fertiliser $\mathrm{N}$ has become so readily accessible.

\section{Sowing and emergence}

Historically, as new tools develop, establishment and management techniques were also re-appraised. In the past (pre-1970's) when pastoral farming in New Zealand was based on white clover to supply $\mathrm{N}$ and build soil fertility, establishment management was white clover management. Pastures were 'permanent', expected to last indefinitely and therefore worthy of time and effort to establish.

\section{Seedbed and sowing}

White clover has a small seed hence small energy reserves and with poor cool season activity, needs shallow sowing $(2-3 \mathrm{~mm})$ in early autumn. Techniques used included prior cropping to reduce soil $\mathrm{N}$, cultivation (ploughing, discing, rolling, etc.) to form a fine, firm seedbed, incorporating fertiliser (superphosphate) and lime for clover growth. Seed was broadcast sown ('Cambridge' roller type drills) at a low ryegrass seed rate to reduce competition 
(10-15kg/ha, white clover $2-3 \mathrm{~kg} / \mathrm{ha})$, covered with a light chain harrow and consolidated with a final pass of the roller to improve seed/soil contact for water uptake and germination. For ryegrass, sowing conditions are not as critical as it is capable of emerging from depths of $20 \mathrm{~mm}$, with $5-10 \mathrm{~mm}$ being the optimum. Under these conditions, emergence rates were consistently $>70 \%$ for both grass and clovers.

In this project, nearly all the sowing was by direct drilling, chiefly the Baker X slot, even in cultivated soil, no roller drills were used. The main disturbing fact was that the low emergence rates overall suggested more than half of all the seed being sown did not come up (Table 2), not too important for the grass sown at a high $20-25 \mathrm{~kg} / \mathrm{ha}$ in this grass/high soil fertility/fertiliser $\mathrm{N}$ regime, but for the slower growing clover it is critical. At $2 \mathrm{~kg} / \mathrm{ha}$ of bare white clover seed, there are around $280 \mathrm{seeds} / \mathrm{m}^{2}$, more than enough at the expected $70 \%$ emergence rate, but at $30-40 \%$ emergence and $30 \%$ survival, white clover plant numbers can be critically limited. Perennial ryegrass at $20 \mathrm{~kg} / \mathrm{ha}$ provides around 1000 seeds $/ \mathrm{m}^{2}$. Research has shown that $8-10 \mathrm{~kg} / \mathrm{ha}$ is sufficient even at lower soil fertility, higher rates cause earlier closure of the canopy and accelerating the timing of the first grazing, putting even more stress on the limited number of clover plants from competition over that critical first 2-3 months.

\section{Soil condition and consolidation}

In direct drilled situations, clover emergence was better on the lighter sandy soils and poorer on heavier clay soils (Table 2). On lighter soils, the passage of the coulters tends to disturb the soil more to form a better seedbed compared to the more plastic clay soils. This was particularly evident in the 'grass to grass' situations where the soil surface tended to be moister but the drill slot more glazed. Some scarification of cultivation of these types of soils would be better. In the fully cultivated soils, emergence was no better, but in this case, the unconsolidated soil was often too loose and soft for consistent accurate seed placement. Even when the seed was allowed to fall onto the surface there was little improvement, possibly as the small clover seed fell too deep between the soil particles. Pre-sowing rolling is needed to reduce this, while post sowing consolidation to increase seed/soil contact may also have been beneficial.

\section{Management of establishing white clover}

In the past, establishment grazing management was white clover management. Systems involved frequent on/off grazing to reduce grass competition and maintain a good light environment over the first year to encourage clover development (Brougham 1958, 1959, Brougham et al. 976). From germination of the seed, white clover progresses through three distinct morphological phases (Thomas 1987). First is a small, compact, rosette seedling phase (2-3 branches, $10-20 \mathrm{~mm}$ spread) lasting 1-3 months or most of winter, hence the critical importance of frequent but light early grazings. The following tap-rooted phase with rapid expansion in the first spring/summer (16-20 branches, $300 \mathrm{~mm}$ spread) that must be encouraged if a strong clover base is to be achieved (Brock et al. 2000). After 1-2 years the taproot dies and these large plants fragment into small plants (4-6 branches, $50-70 \mathrm{~mm}$ spread), the 'normal', 'mature' clonal phase typical of white clover in permanent pastures. By contrast, ryegrass attains such 'morphological maturity' within 6 months of sowing (Brock unpublished data).

In this group study, the importance of grazing management in the first year was clearly demonstrated where paddocks set stocked from lambing to weaning showed a reduction in size of plants during spring compared to those rotationally grazed by cattle (Table 4). So far ryegrass has been portrayed as a competitor for clover and generally detrimental to its early establishment. True in the early seedling phase and through the early spring, but ryegrass can also be an important benefactor to white clover by protecting it from overgrazing. Direct drilling in rows may give more space for clover to grow into, but it also allows more access for animals to overgraze the clover (stolon stripping) and reduce its spread, as with set stocking. By comparison, broadcast sowing with more uniform distribution of grass reduces stock access to the clover, providing greater protection from preferential overgrazing.

Soil fertility has a major impact on clover establishment. In a new pasture with high soil fertility and where fertiliser $\mathrm{N}$ is used, clover struggles to compete and develop unless the grass can be kept in control through effective grazing management. By contrast, lowering soil fertility (as with cropping and not applying fertiliser N) will favour clover because of its $\mathrm{N}$ fixing ability, without affecting grass establishment. Although the grass will not grow as well, it will survive to respond at a later stage as soil fertility builds through $\mathrm{N}$ fixation or $\mathrm{N}$ fertiliser is applied. For example, sowing new pasture after Triticale silage crops has resulted in pastures with higher clover content. If high levels of 
clover are desired, do not use $\mathrm{N}$ fertiliser in the first year at least and avoid fast growing winter active Italian ryegrasses. Instead, use of slower establishing tall fescue or perennial ryegrass with novel endophytes (e.g. AR1) with higher acceptability to stock will reduce the pressure on white clover.

\section{Renovation versus new pasture}

Within the farmer group there were clearly different expectations from white clover. Where the emphasis is to maintain a strong clover base in the pasture to maximise soil fertility using $\mathrm{N}$ fixation, clover cultivar is not so important and encouraging the resident clover ecotypes adapted to the local environment and management may be the better approach. In the 'grass to grass' renovation situation, very few clover seedlings survived (Table 3 ) and older clonal material made up the clover base. Therefore it may be best to renovate by direct drilling grass only, using herbicide only if control of resident grasses and weeds is necessary, and then with some more clover-friendly herbicide such as 'Gramoxone' (paraquat). If the clover is run-out as well then establishing a new pasture using cultivation may be necessary.

Where clover is grown chiefly for herbage quality or a change of clover cultivar is desired, full cultivation to remove the old cultivar is required, followed by optimal clover establishment management. Such management appears to be more difficult to achieve on dairy farms, where the adoption of new faster establishing grass cultivars and fertiliser $\mathrm{N}$ technologies has ensured more reliable and higher pasture growth rates compared with the efficient clover $\mathrm{N}$ based system with its biological constraints (Brock \& Hay 2001).

\section{The case for white clover}

If the primary role of $\mathrm{N}$ fixation and building soil fertility for white clover has been negated, there is still a strong case for white clover through recognition of its secondary role, excellent feed value. Despite the problems with establishing white clover in the modern farming context highlighted by this study, research has shown clover based pastures can still out perform fertiliser $\mathrm{N}$ systems (Eerens \& Ryan 2000 ) if managed correctly. The ability of new white clover cultivars to maintain higher clover content in pastures particularly over summer has been demonstrated (Eerens et al. 2001; Woodward et al. 2001).

Change is inescapable and while modern farming techniques and expectations have placed clover at a disadvantage, the challenge now is how to balance the requirements of the pasture species with the expectations of the farming production system. Time is needed to ensure the processes of review, testing and reconciliation take place.

\section{ACKNOWLEDGEMENTS}

The authors wish to thank the members of the 'Clover Up' farmer group for providing on-farm pastures, interest and support, and AgResearch for support facilities. Financial support of the project by the MAF Sustainable Farming Fund, the New Zealand Dairy Board Global Programme, and Agricom (New Zealand) Ltd is appreciated.

\section{REFERENCES}

Brock, J. L.; Hay, M. J. M. 2001. White clover performance in sown pastures: A biological/ ecological perspective. Proceedings of the New Zealand Grassland Association 63: 73-83.

Brock, J. L.; Albrecht, K. A.; Tilbrook, J. C.; Hay. M. J. M. 2000. Morphology of white clover during development from seed to clonal populations in grazed pastures. Journal of Agricultural Science, Cambridge 135: 103-111.

Brougham, R. W. 1958. Interception of light by the foliage of pure and mixed stands of pasture plants. Australian Journal of Agricultural Research 9: 3952.

Brougham, R. W. 1959. The effects of frequency and intensity of grazing on the productivity of a pasture of short-rotation ryegrass and red and white clover. New Zealand Journal of Agricultural Research 2: 1232-1248.

Brougham, R. W.; Ball, P. R.; Williams, W. M. 1976. The ecology and management of white cloverbased pastures. pp. 309-324. In: Plant relations in pastures. Ed. Wilson, J. R. CSIRO, Canberra, Australia.

Caradus, J. R.; Woodfield, D. R.; Stewart, A. V. 1996. Overview and vision for white clover. White clover: New Zealand's Competitive Edge. Agronomy Society of New Zealand Special Publication 11/New Zealand Grassland Association, Grasslands Research and Practice Series 6: 1-6.

Eerens, J. P. J.; Ryan. D. L. 2000. Managing white clover for productive and profitable sheep farming in Southland. Proceedings of the New Zealand Grassland Association 62: 137-140.

Eerens, J. P. J.; Crush, J. R.; Woodward, S. L.; MacDonald, K. A.; Carter, W. A. 2001. Milksolids production from different combinations of perennial ryegrass and white clover cultivars: I Trial design and pasture performance. Proceedings of the New Zealand Grassland 
Association 63: 91-96.

Fraser, T. 2000. Pasture persistence for profits. Meat New Zealand $R$ \& D Report 82.

Thomas, R. G. 1987. Vegetative growth and development. pp. 31-62. In: White clover. Baker, M. J.; Williams, W. M. (Eds.) CAB International, Wallingford.
Woodward, S. L.; MacDonald, K. A.; Carter, W. A.; Eerens, J. P. J.; Crush, J. R. 2001. Milksolids production from different combinations of perennial ryegrass and white clover cultivars: II. Milksolids production and farm profitability. Proceedings of the New Zealand Grassland Association 63: 97-102.

48 - File identification only 